\title{
Construtores e herdeiros: \\ a trama dos interesses na construção da unidade política
}

Builders and Heirs: a Net of Interests

in the Formation of a Political Unity

IImar Rohloff de Mattos

Professor da Pontifícia Universidade Católica do Rio de Janeiro.

\section{Resumo}

A compreensão da unidade do Império do Brasil relaciona-se, na conjuntura da emancipação política, à ação política levada a efeito por antigos colonizadores e colonos, motivada de modo direto ou não quer pelos eventos relacionados ao "enraizamento de interesses portugueses e sobretudo o processo de interiorização da metrópole no Centro-Sul", quer pelos acontecimentos do Velho Reino desde 1820. Operando com expectativas, valores e imagens referidos a uma dupla herança - a de um território e a de uma denominação, "Império do Brasil" -, aqueles que se apresentavam como Construtores na cidade do Rio de Janeiro, ao colocarem em plano destacado a questão do Estado, forjavam uma unidade que era não só a condição para a delimitação das clivagens, que a eles próprios distinguiam, como o pressuposto para 0 exercício de uma "expansão para dentro", marco distintivo da formação do Império do Brasil.

\begin{abstract}
In the period of its political emancipation, the understanding of the Brazilian Empire unity relates to the political action taken by both settlers and old colonists motivated, directly or not, by the events related to the "the establishment of Portuguese interests in Brazil and, above all, the reawakening of metropolitan interests in the central-southern region" or by those that took place in Portugal since 1820. Dealing with expectations, values and images referred all to a double heritage - of a territory and also of a name, "Brazilian Empire" -, those who presented themselves, in the city of Rio de Janeiro, as the "builders" of the nation forged a unity, by bringing out the importance of the State, that was not only a condition to deal with the cleavages that separated themselves, but also a precondition to enact an "inland expansion", a distinctive feature of the Brazilian Empire formation.
\end{abstract}

\section{Palavras-chave}

Império do Brasil, identidade nacional, territorialidade, Corte imperial, polítical administração, centralismo.

\section{Keywords}

Brazilian Empire, national identity, territoriality, Imperial Court, politics/administration, centralism. 
"Já podeis filhos da Pátria

Ver contente a mãe gentil

Já raiou a Liberdade

No horizonte do Brasil.

Brava Gente Brasileira,

Longe vá temor servil;

Ou ficar a Pátria livre

Ou morrer pelo Brasil

Os grilhões que nos forjava

Da perfidia astuto ardil

Houve mão mais poderosa

Zombou deles o Brasil."

Evaristo da Veiga

Hino Constitucional Brasiliense [1822]

Octavio Tarquinio de Souza. Evaristo da Veiga. São Paulo: Cia. Editora Nacional, 1939, p.33.

2

Eulalia Maria Lahmeyer Lobo. História do Rio de Janeiro (do capital comercial ao capital industrial e financeiro). Rio de Janeiro: IBMEC, 1978. De acordo com a autora, dos 112.695 habitantes da cidade à época da emancipação política, 48.9\% eram escravos.

3

Machado de Assis. Memórias póstumas de Brás Cubas.- Obra completa. Rio de Janeiro: Aguilar, 1962, vol. 1, p. 542.
Os versos vibrantes de um jovem de quase 23 anos eram a expressão das experiências emocionantes por ele vividas no Rio de Janeiro, em meados do ano de 1822. Mas não apenas por ele. Das páginas redigidas por seu principal biógrafo saltam a tropa e o povo cantando nas ruas da cidade, ao som de duas músicas diversas, uma de autoria do maestro Marcos Portugal e outra de autoria do próprio príncipe D. Pedro, os versos daquele que "sem ser figura saliente em nenhum dos sucessos que se desenrolaram, acompanhou-os cheio de entusiasmo"1. Mas das páginas de uma biografia não menos vibrante, a ponto de levar seus leitores a imaginar que, em cenário diverso e em escala menor, reproduzia-se o próprio momento de composição da Marselhesa, pouco mais de três décadas antes, surge não apenas o jovem conformado por aqueles sucessos, mas também o indivíduo que contribuía para a construção da Pátria livre. Por meio de seus hinos, o jovem patriota tornava possivel a uma multidão de homens transformar suas vivências individuais em experiência comum, forjando uma identidade nova. Afinal, o Hino Constitucional Brasiliense não apenas anunciava a constituição de um novo corpo político independente; os versos de Evaristo da Veiga possibilitavam à Brava Gente Brasileira a compreensão das experiências que alvoroçavam seus corações, naquele momento, como o início de um tempo novo - uma Revolução.

Não a todos os 112 mil habitantes da cidade 2 , por certo. E ainda menos aos que, personagens reais ou não, mantiveram-se distantes, espacial e emocionalmente, daqueles sucessos. Fora assim com Brás Cubas, ainda um peralta aos dezessete anos, e por isso mesmo mandado para a Europa, a fim de "tomar juízo", por decisão de seu pai. E de seu criador, sobretudo. De modo certamente não acidental, este já o batizara com o nome de um dos primeiros colonizadores da América portuguesa; escolhera mandá-lo para a Europa no mesmo ano em que Evaristo da Veiga compunha seus hinos patrióticos; e, agora, fazia-o expor de modo significativo a lembrança de seu retorno à cidade, já adulto e formado: "Vim. Não nego que, ao avistar a cidade natal, tive uma sensação nova. Não era efeito da minha pátria política; era-o do lugar da infância, a rua, a torre, o chafariz da esquina, a mulher de mantilha, o preto do ganho, as cousas e cenas da meninice, buriladas na memória. Nada menos que uma renascença"3. A experiência do exilio propiciava uma sensação nova no momento do retorno, a qual não era efeito da minha pátria política. A ausência do cenário que alvoroçara os corações de jovens e adultos, da tropa e do povo, possibilitava a apresentação de um outro cenário - nada menos que uma renascença - por Machado de Assis a um leitor 
4

Francisco de Paula Ferreira de Rezende. Minhas recordações. Rio de Janeiro: José Olympio, 1944, p. 67.

5

J. Capistrano de Abreu. Caminhos antigos e povoamento do Brasil. 2a ed. Rio de Janeiro: Briguiet, 1960, p. 134

6

Octavio Tarquinio de Souza. Op. cit., p. 24. distante do tempo daqueles acontecimentos; possibilita-nos hoje perceber como a Revolução da Independência tendera a apagar as ainda fluidas fronteiras entre as esferas pública e privada, ao inundar como uma grande onda representativa da questão do Estado todos os âmbitos da vida comum.

Do momento em que Brás Cunha vinha e o primeiro imperador partia, um outro personagem, esse não ficcional, recordaria que "nasci e me criei no tempo da regência; e nesse tempo o Brasil vivia, por assim dizer, muito mais na praça pública do que mesmo no lar doméstico; ou, em outros termos, vivia em uma atmosfera tão essencialmente política que o menino, que em casa muito depressa aprendia a falar liberdade e pátria, quando ia para a escola, apenas sabia soletrar a doutrina cristã, começava logo a ler e aprender a

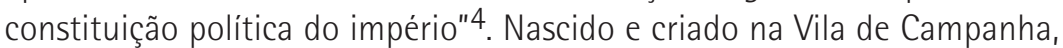
na província de Minas Gerais, aquele que gostava de se identificar como um lavrador, Francisco de Paula Ferreira de Rezende, não duvidava que sua experiência não era exclusiva, o mesmo devendo ter ocorrido com inúmeros outros meninos em outros pontos do Império. É bastante provável que quase todos ao menos imaginassem ser sobretudo na Corte imperial, onde a praça pública impunha-se ao lar doméstico; o povo e a tropa continuavam projetando sua sombra sobre o preto do ganho e a mulher de mantilha; e as discussões e disputas em torno de projetos políticos, que continuavam a expressar interesses inconciliáveis, pareciam não ter fim.

Tais circunstâncias não escapariam a Capistrano de Abreu, uma década após a proclamação da República. A propósito da cidade que se tornara Capital Federal, ele afirmaria que "por ter sido uma vez cabeça, continua ainda e continuará muito tempo ainda, apesar da ameaça guaiana: se não foi aqui que primeiro se concebeu a idéia de uma nação, aqui pelo menos se realizou este sonho que bem de perto esteve de esvair-se como sonho" 5 . No momento em que a onda jacobina começava a refluir e o novo pacto político oligárquico, referendado pela "política dos Estados", parecia afastar as ameaças de secessão, aquele que deveria ser, para o historiador cearense, o papel da cidade - a cabeça de um corpo político e de uma nação -, não fazia senão revelar uma espécie de destino ou vocação, continuando a se contrapor à cidade de Brás Cubas.

Experiências diversas - expressadas de modos diferentes e em momentos variados - trazem, para o primeiro plano, algumas das imagens - fortes e duradouras - presentes no Rio de Janeiro no momento da emancipação política: a Gente brasileira; a constituição brasiliense; os filhos da pátria; a praça pública; a cidade como cabeça do Brasil. Experiências diversas que sugerem, ainda desta vez, que talvez seja prudente evitar reduzir a um único fator explicativo a trama dos interesses ali presentes na construção da unidade política do Império do Brasil, à época da emancipação política, ao mesmo tempo em que parecem alertar para o fato de que aquela construção somente se completaria em meados do século, sob a direção saquarema. Mas experiências que sugerem ainda que o momento que pode ser entendido como o do final de uma trajetória, constitui também o momento no qual aquela "outra cidade" rememorada por Brás Cubas se revela plenamente, não apenas como necessariamente complementar à primeira, mas sobretudo como reveladora de uma fisionomia nova.

De modo a destacar algumas dessas experiências, assim como alguns dos interesses ali presentes, retorno ao Hino Constitucional Brasiliense e a Evaristo da Veiga.

Ao mesmo tempo em que cantavam a constituição de um corpo político independente - ou ficar a pátria livre ou morrer pelo Brasil - e sublinhavam uma individuação - a Brava Gente Brasileira -, e assim proclamavam tanto o fim do Reino Unido quanto a fratura irreversível da Gente portuguesa, a quem Evaristo louvara poucos anos antes ${ }^{6}$, os versos de agosto de 1822 propunham ainda uma relação, agora entendida como irreversível, entre Liber- 
7

Joaquim Manoel de Macedo. Ano bibliográfico brasileiro, 1876. Rio de Janeiro: Tipografia imperial, 1880.

8

S. a Sisson. Galeria dos Brasileiros ilustres. Vol. 1. Brasília: Senado Federal, 1999, p. 262.

9

Carl Schmitt. Teoria de la Constitución. Madrid, 1934.

10

O Tamoio, edição de 2 de setembro de 1823. dade e Constituição. Uma relação que marcaria de forma indelével a trajetória de Evaristo da Veiga.

Assim, entre a composição dos inúmeros hinos patrióticos e o retorno de Brás Cubas ao Rio de Janeiro, Evaristo da Veiga se tornara livreiro de prestígio, com sua loja na rua dos Pescadores no 49 sendo "o ponto de reunião diária dos mais importantes chefes liberais"7; tornara-se, ainda, redator da Aurora Fluminense, "a tribuna em que se advogavam os interesses públicos, o púlpito de que baixavam lições para o povo"8; e elegera-se deputado geral. Novas e variadas experiências, cujo traço dominante comum era representado pela permanência de sua fé constitucional. "Oueremos a Constituição; não queremos a Revolução", proclamaria o intrépido redator logo após o Sete de Abril, reafirmando um projeto político. Em 1831, ele começava a dissociar fé constitucional de revolução; acreditava mesmo ser possível sobrepor-se à torrente dos fatos, controlando o curso desta última.

A cultura política do constitucionalismo conformava a figura de Evaristo da Veiga. A defesa intransigente da Constituição era entendida como a condição para a existência da Liberdade e da Independência; ela se convertia no principal mecanismo jurídico-político para limitar o poder do Estado, por meio da separação entre poder e direito, uma vez que o direito deixava de ser entendido como uma manifestação do poder para se converter na forma de limitá-10 ${ }^{9}$. Os versos do Hino Constitucional Brasiliense o revelavam; e não por outra razão passariam a ser identificados como o Hino da Independência, algum tempo depois.

Mas os versos de 1822 não propunham apenas isso. Eles propunham, também, uma relação de implicação entre um continente - o Brasil, um território em cujo horizonte já raiou a Liberdade - e um conteúdo - os filhos da Pátria. E, ao fazê-lo, ainda que, talvez, de modo não consciente para seu próprio autor, revelavam a filiação daquele que era o construtor ativo de um corpo e uma identidade política novos a uma tradição que remontava às propostas do reformismo ilustrado português. Uma tradição que, igualmente, conformava suas experiências. 0 construtor era também um herdeiro; o herdeiro, sobretudo, de um nome e um território. E essa herança definiria também os marcos de uma construção.

Mas não apenas Evaristo da Veiga se distinguiria como um construtor e um herdeiro no quadro da emancipação política no Rio de Janeiro. Se o biógrafo pode dizer que Evaristo não era figura saliente em nenhum dos sucessos que se desenrolaram, é porque a onda que, então, tudo inundava punha em destaque inúmeras outras figuras, como a de José Bonifácio. 0 velho Andrada havia retornado à terra natal em 1819, após uma longa estadia de trinta e seis anos na Europa, particularmente em Portugal, onde exercera diferentes cargos e funções, tendo sido secretário da Academia Real de Ciências de Lisboa, a partir de 1812. Dirigindo-se ao primeiro imperador do Brasil, em setembro de 1823, aos sessenta anos de idade, ele lembrava que "V.M. bem sabe que [...] preguei a Independência e liberdade do Brasil, mas uma liberdade justa e sensata debaixo das formas tutelares da Monarquia Constitucional, único sistema que poderia conservar unida e sólida esta peça majestosa e inteiriça de arquitetura social desde o Prata ao Amazonas, qual a formara a mão onipotente e sábia da Divindade". 10 Sublinhava com orgulho, por meio das páginas oposicionistas d' 0 Tamoio, a construção que empreendera, condição para a preservação de uma herança que procurava gerir de modo consciente. Uma herança que expressava uma tradição, e esta o conformava fortemente.

Construtores porque herdeiros, o jovem Evaristo e o velho Andrada assemelhavam-se e diferenciavam-se a um só tempo. Assemelhavam-se e diferenciavam-se de muitos outros contemporâneos, cujas trajetórias de vida também foram fortemente marcadas pelos sucessos da emancipação política, propiciadores de escolhas comuns e posicionamentos diversos, de experiên- 
11

Cf. Gilberto Velho. Projeto e metamorfose. Rio de Janeiro: Jorge Zahar, 1994.

12

Francisco Adolfo de Varnhagen. História Geral do Brasil. Vol.2. 9a ed. integral. São Paulo: Melhoramentos, 1978, p.25.

13

Pedro Puntoni. A guerra dos bárbaros. Povos indígenas e a colonização do sertão. Nordeste do Brasil, 1650-1720. São Paulo: Hucitec/USP/Fapesp, 2002.

14

Giovanni Arrighi. O longo século XX. Rio de Janeiro: Contraponto; São Paulo: Editora da UNESP, 1996.

15

L. Filipe Barreto. Os descobrimentos e a ordem do saber. Lisboa: Gradiva, 1987.

16

Memória de D. Rodrigo de Sousa Coutinho (1 ${ }^{\circ}$ Conde de Linhares) sobre os melhoramentos dos domínios de S. Majestade na América. Coimbra: Editora Limitada, 1947. cias compartilhadas e relações conflitantes. Trajetórias que expressavam uma deliberação consciente a partir do campo de possibilidades em que se inseriam. Trajetórias que reafirmavam a cada instante uma conduta organizada com o objetivo de atingir finalidades específicas, mas que não deixavam de manifestar limitações e constrangimentos de diferentes tipos. Trajetórias reveladoras tanto de projetos políticos quanto da trama de interesses em que se inseriam. ${ }^{11}$

\section{Périplo Solar}

Tento explicar melhor, começando pela herança: um nome; um território e sua "cabeça"; uma nação. E isso porque ela conforma, em larga medida, quase todos os projetos, expressando-se em clivagens diversas.

Desde a Restauração de 1640, modificava-se em ritmo acelerado o valor e a importância atribuídos aos domínios e às conquistas da América portuguesa no conjunto da Monarquia. Demonstrava-o não apenas a carta patente de D. João IV, de 1645, dispondo que os primogênitos dos reis e herdeiros presuntivos da Coroa se intitulassem, daí em diante, "Príncipe do Brasil"12, mas também aquilo que foi recentemente caracterizado como o movimento ou processo de "ocidentalização" da colônia, sob o incentivo das autoridades coloniais ${ }^{13}$. 0 progressivo deslocamento do eixo das conquistas e dos domínios portugueses para o Atlântico não deixava de ser também, ao menos em parte, o deslocamento da aventura marítima para aquela do sertão; movimento esse que tendia, numa outra perspectiva, a reafirmar a lógica do poder territorialista, que caracterizava os governantes ibéricos em sua vocação para identificar o poder com a extensão e a densidade populacional de seus domínios ${ }^{14}$. Demonstravam-no ainda os diversos esquadrinhamentos do território da América portuguesa, no decorrer do século XVIII, enriquecedores do "campo da geografia/antropologia colonial" 15 , acervo de dados necessários a decisões de natureza política, como a conclusão de acordos diplomáticos definidores dos limites entre as conquistas dos soberanos ibéricos, conforme exemplifica o Tratado de Madri de 1750, o qual retratava a contigüidade das conquistas portuguesas no Novo Mundo.

Demonstrava-o ademais, embora já nos quadros do reformismo ilustrado e como expressão da crise do sistema colonial de base mercantilista, uma Memória redigida por Dom Rodrigo de Sousa Coutinho em 179716. Nela, tendo como objetivo oferecer a S. Majestade conselhos visando à adoção de medidas que reformassem a estrutura política, administrativa e econômica dos "Domínios Ultramarinos", Dom Rodrigo enfatizava "este inviolável e sacrossanto princípio da Unidade, primeira base da Monarquia, que se deve conservar com o maior ciúme, a fim que o Português nascido nas Quatro Partes do Mundo se julgue somente Português", principio do qual derivava outro "de que as relações de cada Domínio Ultramarino devem em reciproca vantagem ser mais ativas e animadas com a Metrópole, do que entre si, pois que só assim a União e a prosperidade poderão elevar-se no maior auge". E concluia que ambos os princípios deveriam ser aplicados "aos mais essenciais dos nossos Domínios Ultramarinos [...] as Províncias da América, que se denominam com o genérico nome de Brasil". 0 destaque dado ao Brasil derivava de sua posição geográfica estratégica e de suas riquezas naturais, projetandose na possibilidade da formação de um só corpo político com Portugal.

Ao pôr em evidência "o genérico nome de Brasil", a Memória contribuia para reforçar a representação de uma unidade espacial e de uma contigüidade territorial, a qual se desdobrava na referência à possibilidade de se "ocupar o verdadeiro limite natural de nossas Possessões no Sul da América, que é a margem setentrional do Rio da Prata". Unidade e contigüidade que logo se traduziriam na denominação Império do Brasil. Empregada, desde então, sobretudo por aqueles que no Reino teciam os fios da política reformista, a denominação Império do Brasil dizia respeito à parte - um vasto e 
17

José Bonifácio de Andrada e Silva. Escritos políticos. São Paulo: Obelisco, 1964, (grifo meu).

18

Cf. Luciano Figueiredo. "Os sentidos da colonização na América portuguesa". In: Ana Maria Magaldi, Cláudia Alves, José G. Gondra (orgs.). Educação no Brasil: história, cultura e politica. Bragança Paulista: EDUSF, 2003; e para o caso de Pernambuco: Evaldo Cabral de Mello. Rubro veio. $O$ imaginário da restauração pernambucana. Rio de Janeiro: Nova Fronteira, 1986.

19

Cf., entre outros, Oliveira Lima. Dom João VI no Brasil. 1808-1821. Rio de Janeiro: Tipografia do Jornal do Comércio, 1908.

20

Maria Odila Silva Dias. "A interiorização da metrópole (1808-1853)". In: Carlos Guilherme Mota (org.) 1822: dimensões. São Paulo: Perspectiva, 1972

21

Cf. IImar Rohloff de Mattos. O tempo saquarema. A formação do Estado imperial. $4^{\mathrm{a}}$ ed. Rio de Janeiro: Access editora, 1999. contíguo Domínio Ultramarino - de um todo - a Monarquia portuguesa. Uma denominação que encerrava tamanha expressividade que, ainda em 1821, nas "Lembranças e apontamentos" que redigiu aos Deputados da Província de São Paulo às Cortes Portuguesas, José Bonifácio, ao tratar dos "Negócios do Reino do Brasil", dissertaria a respeito da utilidade de se levantar "uma cidade central no interior do Brasil para assento da Regência", apontando o favorecimento que dai derivaria para o "comércio interno do vasto Império do Brasil" 17 .

Mas a esta unidade espacial e contigüidade territorial do Império do Brasil não correspondiam uma unidade e uma centralização políticas. E esta não correspondência contribuía para reafirmar o papel do Reino de Portugal como "a Capital e o Centro de suas Vastas Possessões" quer para lhe assegurar "os meios de figurar conspícua e brilhantemente entre as Primeiras Potências da Europa". A transmigração da Corte portuguesa para o Rio de Janeiro, em 1808, não teria o poder de alterar de modo significativo um quadro que deitava suas raízes tanto nas práticas políticas da Monarquia portuguesa sob os Braganças, quanto na configuração regional que desde cedo distinguira a colonização das "Províncias da América", expressando-se não raro, embora de modo não exclusivo, nas denominadas identidades coloniais ${ }^{18}$.

Não obstante, a instalação da Corte no Rio de Janeiro deflagraria outros processos não menos significativos. De uma parte, ao fazer convergir para a cidade as atenções das demais Províncias da América, e mesmo de certas regiões da América espanhola, a presença da Corte reforçava a imagem já expressa pelo Conde da Cunha, vice-rei no Rio de Janeiro, de que "esta Cidade ... pela sua situação e porto deve ser a cabeça do Brasil". E mais do que isso: ao tornar o Rio de Janeiro o novo centro político e administrativo da Monarquia, estabelecia-se uma dualidade, geradora de uma ambigüidade, somente em parte resolvida pela criação do Reino Unido de Portugal, Brasil e Algarves, em $1815^{19}$. De outra parte, ela propiciava a progressiva diferenciação da área da Corte no conjunto das regiões geradas pela colonização, como resultado, sobretudo, da expansão dos interesses mercantis, financeiros, burocráticos - e nos quais se incluiam os plantadores escravistas -, a qual se beneficiava largamente da íntima conexão entre negócios e política que a Corte joanina potencializara, configurando o que já foi denominado como a interiorização da metrópole 20 . Revelava-o, dentre inúmeros outros casos, a trajetória da família Carneiro Leão. Grandes negociantes no Rio de Janeiro desde o século XVIII, haviam progredido significativamente desde a abertura dos portos, ampliando suas trocas, negociando com o Real Erário, concedendo créditos. Cunhado de Paulo Fernandes Viana, Intendente-Geral de Polícia da Corte, Fernando Carneiro Leão colocaria à disposição daquele os recursos necessários à organização da repartição e à realização das obras que então the competiam, como a abertura de ruas e estradas, a iluminação e calçamento de logradouros. 0 intendente de Polícia da Corte, por sua vez, colaborara na construção de uma das estradas que unia o Sul de Minas à Corte, cortando suas propriedades - estrada significativamente denominada de Estrada da Polícia. 21

Todavia, se a instalação da Corte no Rio de Janeiro contribuíra decisivamente para forjar a imagem do Rio de Janeiro como a cabeça da Monarquia, para a diferenciação da área da Corte e para a difusão da imagem de Brasil - e deste modo alimentava o projeto de um "novo império" -, ela também seria responsável pela negação de um dos princípios definidores daquele todo representado pela Monarquia - ou seja, o Império português -, e ao fazê-lo incidiria de modo irreversível sobre a herança que estamos considerando.

Dom Rodrigo já sustentara ser necessário "criar um poderoso império no Brasil, donde se volte a reconquistar o que se possa ter perdido na Europa". Mas foi com a decisão do Príncipe Regente Dom João de "passar com a Rainha Minha Senhora e Mãe, e com toda a Real Família para os Estados da 
Decreto do Príncipe Regente de Portugal pelo qual declara a sua intenção de mudar a corte para o Brasil, e erige uma Regência para Governar em sua ausência, em Correio Braziliense ou Armazém Literário. (edição fac-similar). São Paulo: Instituto Uniemp/ Labjor/Imprensa Oficial do Estado, s.d., p. 5.

\section{3}

Cf. Roberto Macedo. História Administrativa do Brasil. Vol. VI.Rio de Janeiro: DASP,1964, p. 38.

24

Correio Braziliense, p.63.

\section{5}

Cf. Michel Chartier. "Impérios". Enciclopédia Einaudi - Estado - Guerra. Vol. 14. Lisboa: Imprensa Nacional/Casa da Moeda, 1989. A respeito das experiências imperiais na Idade Moderna, cf. também Anthony Pagden. Señores de todo el mundo. Ideologías del imperio en España, Inglaterra y Francia (en los siglos XVI, XVII y XVIII). Barcelona: Península, 1997.

26

Cf. Antonio Negri e Michael Hardt. Império. Rio de Janeiro: Record, 2001.

\section{7}

Cf. Marcia R. Berbel. A nação como artefato: deputados do Brasil nas Cortes portuguesas, 1821-1822. São Paulo: Hucitec/Fapesp, 1999.

28

Cf. Quentin Skinner. Liberdade antes do liberalismo. São Paulo: Editora da Unesp, 1999.

29

Cf. Evaldo Cabral de Mello. A ferida de Narciso. Ensaio de história regional. São Paulo: SENAC São Paulo, 2001.
América, e estabelecer-Me na cidade do Rio de Janeiro"22, que o projeto de um "novo império" ganharia novo alento. Ela seria apregoada ao mundo por meio do Manifesto de $1^{\circ}$ de maio de 1808 , que além de declarar guerra à França, preparando a invasão da Guiana Francesa, anunciava que "a Corte de Portugal levantará a sua voz do seio do novo império que vai criar"23.

Desde Londres, atento àqueles acontecimentos, o redator do Correio Braziliense não hesitaria em emitir sua opinião. No mês seguinte, por intermédio dos Pensamentos vagos sobre novo Império do Brasil, Hipólito José da Costa sustentaria que: "o Principe do Brasil, que, por parte de Sua Mulher, é o único herdeiro legitimo da Monarquia espanhola, deve apossar-se de tudo o que the ficar ao capto, antes que o inimigo comum tome medidas convenientes, para se afirmar por tal maneira, no trono de Espanha, que até as Colônias the não escapem.[...] Não entrarei aqui na discussão dos limites que deve ter o Império do Brasil, e até que ponto o Príncipe Regente poderia com prudência usar dos direitos que tem ao todo das Colônias de Espanha"24.

As vozes do letrado e do soberano absolutista, assim como a do arauto do liberalismo, não deixavam de destacar o valor do Império do Brasil. Mas destacavam, sobretudo, que a Monarquia se definia por uma concepção clássica de império. Ela permanecia sendo conformada por uma concepção dinástica, propiciadora e legitimadora a um só tempo de uma organização hegemônica que transcendia os quadros étnicos ou políticos naturais, não necessariamente contínuos no espaço25. E tinha o seu sentido definido por uma tendência a um certo tipo de dominação universal, pela pretensão a um domínio ilimitado em três dimensões: o espacial, o temporal e o ideológico 26. Conformação e sentido presentes tanto nos argumentos de natureza dinástica, expostos por Hipólito José da Costa para defender os direitos dos Braganças sobre as colônias espanholas na América, quanto na decisão da Corte instalada no Rio de Janeiro de ocupar a Guiana Francesa e a Banda Oriental do Uruguai, decisão que não deixava de reafirmar a lógica do poder territorialista.

Todavia, aquelas proposições, conquistas e ocupações não deixavam de contrastar com a limitação que um outro império - o Império britânico - começara a impor ao projeto de "novo império": o Tratado de Aliança e Amizade de 1810 restringia o tráfico negreiro para os territórios americanos de Portugal às colônias portuguesas na África.

Assim, a política externa de Dom João torna possivel a compreensão de como, na relação Império do Brasil-Monarquia lusa, a parte herdaria as restrições que iam se apresentando ao todo em sua pretensão a um domínio ilimitado, ao menos em termos espaciais.

\section{Gente Brasileira}

Expressão do reformismo de corte ilustrado que sustentava as proposições contidas na Memória, o princípio da monarquia centralizada seria acolhido pelos revolucionários portugueses de 1820, empenhados em regenerar o velho Reino. Balizadas pelos pressupostos liberais, as medidas de cunho centralizador emanadas das Cortes provocariam reações diversas no Reino do Brasil $^{27}$. Na cabeça tropical do Reino Unido, elas seriam repudiadas por aqueles que receberiam de Silvestre Pinheiro Ferreira a designação "partido brasileiro". Nas demais províncias, em especial naquelas do "Norte", apresentavam-se os que propugnavam a adesão ao "sistema das Cortes de Lisboa" ao lado dos que, em nome da defesa de uma autonomia alimentada tanto pela tradição colonial quanto pela teoria neo-romana 28 dos estados livres, propunham uma relação diversa com a Corte do Rio de Janeiro, dominada no seu entender pelos "branquinhos do Reino"; naquela parte do Reino do Brasil, os sucessos de 1821 e 1822 pareciam ecoar os de 1817, expressando-se em identificações como "patriotas" ou "pernambucanos"29. 
30

Silvestre Pinheiro Ferreira. "Cartas sobre a revolução do Brasil". In: Idéias políticas. Rio de Janeiro: PUC-Rio/Conselho Federal de Cultura/Editora Documentário, 1976.

31

José Bonifácio de Andrada e Silva. "Memória sobre a necessidade e utilidade do plantio de novos bosques em Portugal". In: Edgard de Cerqueira Falcão. Obras científicas, políticas e sociais. Vol. 1. São Paulo: Revista dos Tribunais, 1965, ver também Valdei Lopes de Araújo. A experiência do tempo. Modernidade e historicização no Império do Brasil (1813-1845). Tese de doutorado. Rio de Janeiro, Pontificia Universidade Católica do Rio de Janeiro, 2003.

32

Citado por Kenneth Maxwell. A devassa da devassa. A inconfidência mineira: Brasil e Portugal, 1750-1808. Rio de Janeiro: Paz e Terra, 1977, p. 32

33

Luis dos Santos Vilhena. A Bahia no século XVIII. Vol. 3. Salvador: Editora Itapuã, 1969, p.900.

34

Cf. Pedro Puntoni. Op. cit., p.287.

35

Citado por Kenneth Maxwell. Op. cit., p. 31.

36

Cf. István Jancso e João Paulo G. Pimenta. "Peças de um mosaico (ou apontamentos para o estudo da emergência da identidade nacional brasileira)". In: Carlos Guilherme Mota (org.). Viagem incompleta. A experiência brasileira (1500-2000). Formação: histórias. São Paulo: SENAC, 2000.
"Decidiu-se enfim a sorte do Brasil; quebrou-se o nexo que unia suas províncias a um centro comum; e com a dissolução do Brasil se consuma a dissolução da monarquia"30, escrevia Silvestre Pinheiro Ferreira na quarta das Cartas sobre a Revolução do Brasil, em 1821, sob o impacto dos acontecimentos do Pará e da Bahia, dos quais resultaram a adesão daquelas províncias ao "sistema das Cortes de Lisboa". A preocupação ali contida revelava, entre outras coisas, a abrangência alcançada pelo genérico nome de Brasil, como já o demonstrara, aliás, a elevação das Províncias da América à condição de Reino do Brasil em 1815, assim como o Rio de Janeiro era representado como o centro comum que se contrapunha a Lisboa. A quebra do nexo que unia suas províncias a um centro comum era também, e sobretudo, a ruptura de uma unidade política, que poderia se traduzir na fragmentação de um território. Muito mais do que um simples observador de tudo isto, José Bonifácio provavelmente deve ter se recordado, então, de uma memória de sua autoria, publicada em 1815, na tentativa de compreender os acontecimentos em curso e de neles poder intervir. Nela, recorrendo aos conhecimentos adquiridos em sua formação como mineralogista, o Andrada associava a decadência do Reino de Portugal à desertificação - isto é, à desagregação do solo, visto ser a areia um conjunto de partículas isoladas que perderam o principio aglutinador -, a qual resultava do abandono dos campos e da exploração predatória dos bosques, relacionados, por sua vez, ao fato de os portugueses terem se tornado fidalgos extravagantes desde a aventura das navegações. No seu entender, a solução para ambos os problemas era a mesma, uma vez que os fidalgos portugueses agiam no corpo moral de Portugal da mesma forma que a areia sobre o corpo mineral: tratava-se de restaurar o principio aglutinador pela ação de uma autoridade única e centralizada 31 .

Mas a um nome e a um território agregava-se uma outra dimensão daquela herança, não menos significativa.

Dom Rodrigo de Sousa Coutinho pretendia que o Português nascido nas Quatro Partes do Mundo se julgue somente Português, revelando que a unidade que perseguia se desdobrava na preocupação com o povoamento do território, uma vez que - como já fora afirmado pelo Duque Silva-Tarouca havia mais de quatro décadas - "a povoação é, ao meu fraco entender, o tudo: não servindo de nada muito mil léguas de deserto"32. As preocupações dos letrados ilustrados repercutiam no mundo americano, propiciando ao professor régio Luís dos Santos Vilhena dizer, na cidade de Salvador, no primeiro ano do século XIX, em suas Notícias soteropolitanas e brasílicas, que "População é o primeiro assunto dessas reflexões"33. No momento em que o império português deixava de ser compreendido como o orbe cristão, passando a ser representado como o espaço da "civilização"34, as preocupações com o povoamento do território conduziam a uma redescoberta e revalorização do nativo, que já haviam se manifestado na proposição do futuro Marquês de Pombal de "abolir toda a diferença entre portugueses e tapes, privilegiando e distinguindo os primeiros quando casarem com as filhas dos segundos; declarando que os filhos de semelhantes matrimônios serão reputados por naturais deste reino e nele hábeis para ofícios e honras" 35 .

As proposições no sentido de abolir as exclusões baseadas nos "defeitos de sangue" tendiam a ampliar a Nação portuguesa. A pretensão de que todos se julgue $(m)$ somente Português não era suficiente para apagar, contudo, as diferenças entre portugueses europeus e portugueses americanos, ainda que entre estes não se incluíssem as "nações africanas". Uma denominação - portugueses americanos - que se somava a muitas outras que expressavam as múltiplas identidades construídas ao longo do processo colonizador, nas diferentes regiões coloniais, como "paulistas", "pernambucanos", "bahienses", "filhos de Minas" ou ainda "patriotas"36. E também "brasileiros".

Trajetória peculiar a de brasileiro. De início, fora apenas o nome de uma profissão. Com o tempo passara a designar aqueles portugueses que, tendo 
37

Cf. Ilmar Rohloff de Mattos. "Um 'País Novo': a formação da identidade brasileira e a visão da Argentina". In: A visão do outro: seminário Brasil-Argentina. Brasília: FUNAG, 2000.

\section{8}

Cf. Ilmar Rohloff de Mattos. "Nem liberal nem corcunda: D. Pedro I no imaginário da boa sociedade imperial". In: D. Pedro: Imperador do Brasil, Rei de Portugal. Do absolutismo ao liberalismo. Porto: Actas do Congresso Internacional, 2001

39

Cf. Ilmar Rohloff de Mattos. O tempo saquarema. A formaç̧ão do Estado imperial.

40

Citado por José Honório Rodrigues. Independência: revolução e contra-revolução. A evolução política. Rio de Janeiro: Francisco Alves, 1975, p. 115.

\section{1}

A respeito dos colonizados, cf. Ilmar Rohloff de Mattos. $O$ tempo saquarema. A formação do Estado imperial.

\section{2}

Cf. Octaciano Nogueira. Obra política de José Bonifácio. Brasilia: Senado Federal, 1973, p. 86.

\section{3}

Auguste de Saint-Hilaire. Viagem pelas provincias do Rio de Janeiro e Minas Gerais. Belo Horizonte: Itatiaia, 1975. vivido nas terras americanas e ali enriquecido, retornavam à pátria de origem, à terra de seus pais. $E_{1}$ ao que parece, foi tal circunstância que levou Hipólito José da Costa a denominar Correio Braziliense o periódico que editava em Londres, porque destinado aos naturais do Brasil, reservando o nome brasiliano para o indígena. De modo até certo ponto irônico, Silvestre Pinheiro Ferreira qualificaria como brasileiro o partido constituido por aqueles interesses que haviam prosperado no Rio de Janeiro durante a permanência da Corte portuguesa, os quais, surpreendidos pelas medidas de cunho centralizador das Cortes de Lisboa, ameaçadoras em larga medida dos privilégios que os distinguiam, passaram a disputar abertamente a posição preponderante no Reino Unido - isto é, na Monarquia -, uma disputa que se desdobraria na emancipação política ${ }^{37}$. Nestes termos, o Dia do Fico não apenas simbolizava, em si, o momento de uma fundação - a fundação do Império do Brasil -, como se o Príncipe D. Pedro reproduzisse, mais de quatro séculos depois, o ato de um outro fundador, o mestre de Avis, que desistira de trocar Portugal pela Inglaterra, vencido pelo argumento de Rui Pereira ${ }^{38}$. 0 Dia do Fico anunciava, outrossim, uma mudança de significação, brasileiros sendo, desde então, os que transmutados de força social em uma força política, e jogando com o próprio futuro, tinham também decidido ficar, não obstante as clivagens que os distinguiam, construidas a partir da fonte que deveria legitimar uma soberania - liberais e absolutistas; "aristocratas" e "democratas"39.

Em sua radical defesa da unidade e da centralização, os liberais de 1820 sustentavam, por ocasião da discussão do artigo 20 da Constituição em elaboração pelas Cortes, que a Nação portuguesa era a união de todos os portugueses de ambos os hemisférios. Contra tal definição erguer-se-ia a voz de Cipriano Barata, que defendia se dissesse "de todos os portugueses de todas as castas de ambos os hemisférios". Afirmava o representante da Bahia não ser isto indiferente, uma vez que no Brasil havia portugueses brancos europeus, portugueses brasileiros, mulatos, crioulos do país, da costa da Mina, de Angola, cabras, caboclos ou índios naturais do país, mamelucos, mestiços, pretos crioulos e negros da Costa da Mina, Angola, etc., para alertar, ao cabo, que "a falta de cuidado nestes artigos pode fazer grande mal, porque toda a gente de cor no Brasil clamaria que Ihes queriam tirar os direitos de cidadão e de voto; é por isso que eu digo que a palavra português no Brasil é equívoca; concluo, pois, que se deve tirar toda a dúvida nos artigos adicionais, ou mesmo aqui; porque todos aqueles habitantes do Reino do Brasil seguem a mesma religião, falam a mesma língua, obedecem ao mesmo Rei, abraçam e defendem a mesma Constituição livre". 40

Ao exemplificar como a palavra português no Brasil é equívoca, trazendo para o primeiro plano a grande massa de colonizados ${ }^{41}$ produzida pela colonização, a fala de Cipriano Barata revelava não só a diversidade de elementos constitutivos da parte americana da Nação portuguesa, os quais podiam emergir em decorrência da concepção de nação com a qual operava, mas sobretudo um conteúdo caracterizado por uma infinidade de contradições sociais e raciais.

0 momento em que Cipriano Barata discursava nas Cortes portuguesas - agosto de 1822 - coincidia com o momento em que Evaristo da Veiga diferenciava a Gente Brasileira daquela Portuguesa, nos versos do Hino Constitucional Brasiliense. A constituição brasiliense fazia emergir os brasileiros. Propondo-se a conter todos aqueles que aderiam a uma causa, o novo conteúdo atribuído a brasileiro apresentava-se mais abrangente do que brasiliense, e parecia oferecer-se a todas as castas enumeradas por Barata.

Ao enunciar de modo explícito o novo significado de um antigo nome - "Brasileiro é para mim todo o homem que segue a nossa causa, todo o que jurou a nossa independência"42 -, José Bonifácio abria caminho para a constatação de Auguste de Saint-Hilaire - "Havia um país chamado Brasil; mas absolutamente não havia brasileiros"43. 
44

Cf., respectivamente, Sérgio Buarque de Holanda. "A herança colonial: sua desagregação". In: - (org.) História Geral da Civilização Brasileira. São Paulo: Difel, 1975; e Oliveira Lima. O Império brasileiro. 2a ed. São Paulo: Melhoramentos, 1962.

45

Cf. Marco Morel e Mariana Monteiro de Barros. Palavra, imagem e poder. 0 surgimento da imprensa no Brasil do sécuIo XIX. Rio de Janeiro: DP\&A, 2003; e Lúcia Maria Bastos Pereira das Neves. Corcundas e constitucionais. A cultura política da independência (1820-1822). Rio Janeiro: Revan/ FAPERJ, 2003.

46

Sobre os conceitos de Governo da Casa e Governo do Estado, cf. IImar Rohloff de Mattos. $O$ tempo saquarema. A formação do Estado imperial.

\section{7}

Cf. $O$ debate politico no processo de independência. Rio de Janeiro: Conselho Federal de Cultura, 1973. Ver também Lúcia Maria Bastos Pereira das Neves.Op.cit.

48

Cf. Oliveira Lima. Op. cit. Sobre as concepções e formas de governo, Norberto Bobbio. A teoria das formas de governo. Brasilia: Editora da Universidade de Brasilia, 1980.

49

Para ambas as citações, cf. Marco Morel e Mariana Monteiro de Barros. Op. cit., p. 40 e p. 28 , respectivamente.

\section{No Teatro da Corte}

Os acontecimentos dos anos de 1821 e 1822 transformaram uma parte da Monarquia lusa em um corpo político independente - o Império do Brasil. Eles já foram caracterizados por um eminente historiador como uma "guerra civil portuguesa"; deles, diz um outro, teria resultado, no entender de muitos, "um desquite amigável entre os reinos unidos", sem deixar de ressalvar, porém, que não há desquite perfeitamente amigável. ${ }^{44}$. Se a primeira caracterização - que recupera a imagem que muitos dos contemporâneos faziam da emancipação política como uma espécie de arranjo entre os portugueses daquém e dalém mar - sublinha uma fratura irreversível, da qual emergiriam os "cidadãos brasileiros", a segunda possibilita que se perceba tal separação como o derradeiro acordo referido a uma concepção dinástica de império, prenunciando uma outra já diversa.

No Rio de Janeiro - nos salões da Corte e nas ruas; nas lojas maçônicas, nos teatros e na praça pública; por meio de palavras, gritos e gestos, além das centenas de papéis incendiários, manuscritos, impressos e dos onze jornais que circulavam em 1821, propiciadores da constituição de uma opinião pública 45 -, as notícias chegadas de Lisboa, dando conta da atuação das Cortes, eram interpretadas como a ameaça de uma "escravização", conforme revelavam os versos de Evaristo ao associar a constituição brasiliense ao rompimento dos grilhões de uma escravidão. Porém uma escravidão que se diferenciava daquela outra baseada na relação entre o senhor e o escravo, definidora, por sua parte, do caráter da sociedade, então remetida para o âmbito do Governo da Casa - a "outra cidade" -, ao mesmo tempo em que, ainda mais uma vez, punha em destaque o Governo do Estado 46 , do que decorria a transformação do escravo no primeiro dos estrangeiros do novo corpo político.

Mas era uma interpretação que, naqueles meses cruciais, aparecia como o argumento principal que buscava resguardar a posição de autonomia do Reino do Brasil no conjunto do Reino Unido, e assim também preservar sua posição ainda privilegiada - em particular a da cidade do Rio de Janeiro. Um argumento que transparece, em um primeiro momento, nas discussões a respeito da permanência ou do retorno da Família Real para Portugal, contrapondo Tomás Antônio de Vila Nova Portugal ao Conde de Palmela, absolutistas a constitucionalistas 47 ; e, em um segundo momento, na decisão do Príncipe-Regente de ficar no Brasil, em 9 de janeiro de 1822, reafirmada por ocasião tanto da criação do Conselho de Procuradores Gerais das Províncias do Brasil, em 16 de fevereiro de 1822, quanto da convocação de uma Assembléia Geral Constituinte e Legislativa composta por deputados das Províncias do Brasil, em 3 de junho de 1822, decisões que contrapunham o grupo político de José Bonifácio, orientado por uma concepção política de cunho "aristocrático", ao de Gonçalves Ledo, que se distinguia por uma concepção "democrática", o Apostolado ao Grande Oriente do Lavradio 48.

Um argumento que ainda possibilitava que aflorassem concepções

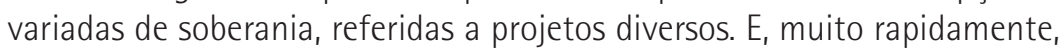
concepções e projetos transbordavam dos salões da Corte para a praça pública, das lojas maçônicas para os jornais, não só procurando ampliar o espaço e o número de participantes das discussões - "... só me proponho a escrever para aquela classe de Cidadãos que não freqüentaram estudos", afirmava o cônego Francisco Vieira Goulart, redator de 0 Bem da Ordem, em 1821 - como também, por vezes, confundindo, de modo extremamente preocupante para muitos, as concepções de liberdade e igualdade, conforme alertava o responsável pelo 0 Conciliador do Reino Unido, em março de 1821, muito provavelmente tendo em mente os sucessos da Praça do Comércio algumas semanas antes: "Bem dirigir a opinião pública a fim de atachar os desacertos populares, e as efervescências frenéticas, de alguns compatriotas, mais zelosos que discretos, e que antes preferem arder a luzir". 49 
50

Cf. Octaciano Nogueira. Obra politica de José Bonifácio. p. 138.

51

Idem, p. 78

52

Idem, p. 141, p. 150 e p.158, respectivamente.

53

Idem, p. 93.

54

Citado por Lúcia Maria Bastos Pereira das Neves. Op. cit., p. 353
Concepções diversas de soberania que não conseguiam deixar de estar necessariamente referidas a uma herança. E se a herança conformava, em larga medida, o campo de possibilidades no qual se movimentavam os seus herdeiros, ela também não deixava de crescer com eles. E dentre os inúmeros herdeiros encontrava-se o próprio Príncipe D. Pedro.

Quando, em outubro de 1821, circularam boatos de que se pretendia aclamá-lo imperador, Dom Pedro lançou um manifesto aos fluminenses advertindo-os do "delírio" e jurando morrer por "três divinais coisas": a religião, o rei e a constituição. Não obstante, expressando os rumos da "guerra civil", sua atitude aos poucos se modificaria; e, nesse movimento, a herança também iria se Ihe impor: a questão da soberania cruzar-se-ia com a da preservação de um vasto território, colocando em primeiro plano a definição das relações entre as províncias e o Rio de Janeiro, e desaguando na opção por um nome.

Ao "Fico" seguiu-se a organização do Ministério de 16 de janeiro, projetando a figura de José Bonifácio.

Por ter em consideração o progressivo afastamento das províncias setentrionais do governo do Rio de Janeiro, desde o início do ano de 1821, o Andrada recomendaria aos Governos Provisórios, por meio da Decisão de Governo de 30 de janeiro, que promovessem a união de todos as províncias com sujeição à Regência de S. A. Real ${ }^{50}$.

Tendo tido conhecimento de que João Soares Lisboa proporia, nas páginas do Correio do Rio de Janeiro, a convocação de uma assembléia constituinte para o Brasil, o Andrada sugeriu ao Príncipe Regente, de modo coerente com suas concepções de cunho "aristocrático", que criasse um Conselho de Procuradores Gerais. D. Pedro aceitou a sugestão, "...porquanto de outro modo este rico e vasto Reino do Brasil ficaria sem um centro de união e força, exposto aos males da anarquia e da guerra civil, e desejando Eu, para utilidade geral do Reino Unido e particular do bom povo do Brasil..."51.

De modo a reforçar a autoridade do Príncipe e reafirmar o papel de cabeça do Rio de Janeiro, outras Decisões do Governo, sempre por inspiração de José Bonifácio, ordenavam que o Rocio do Rio de Janeiro passasse a se denominar "Praça da Constituição"; que não se desse execução a nenhum decreto das cortes portuguesas sem o "Cumpra-se de Sua Alteza Real"; e que sendo o Príncipe Regente Defensor Perpétuo do Reino do Brasil também o era da Província Cisplatina "no mesmo Reino incorporada"52. Todavia, como expressão dos projetos em disputa, assim como da posição singular daquela unidade política, um decreto de 20 de julho determinava que todas as pessoas residentes naquela província que se tivessem comprometido pelo seu patriotismo e brio nacional fossem "atendidas e consideradas como naturais do Brasil, gozando dos mesmos foros e privilégios que a estes forem concedidos pela futura Constituição Política deste Reino" 53 .

Mas do Príncipe Regente acercavam-se também os "democratas". Defensores intransigentes da convocação de uma assembléia constituinte para o Reino do Brasil, eles teriam sua atuação, igualmente, demarcada por uma herança. 0 decreto de 3 de junho de 1822, convocando uma Assembléia Geral Constituinte e Legislativa composta de Deputados das Províncias do Brasil, afirmava - nas palavras do Revérbero Constitucional Fluminense, o jornal redigido por "dois brasileiros amigos da nação e da pátria", Joaquim Gonçalves Ledo e Januário da Cunha Barbosa - a soberania do Povo, pois "nem queremos ser escravos nem o príncipe quer ser despótico", e era apresentado aos "portugueses das quatro partes do mundo" quer como a possibilidade de preservação do Reino Unido, quer como a garantia da "desejada e necessária reunião de todas as províncias do Brasil" 54 .

Uma outra folha - 0 Macaco brasileiro - saudaria o dia 3 de junho como "o maior dia para o Brasil[...]o dia natalício da sua regeneração política". Mas, o que se apresentava também como a tentativa de fundar uma memória 
55

Idem, p. 352 e p. 355 , respectivamente

56

Citado por José Honório Rodrigues. Independência: revolução e contra-revolução. A evolução política. Rio de Janeiro: Francisco Alves, 1975.

57

Cf. Octaciano Nogueira. Op. cit., p.85. seria logo contestado, no Rio de Janeiro e nas províncias. Como foi o caso do jornal baiano 0 Analisador Constitucional que questionava se D. João VI havia consentido a convocação daquela assembléia, desafiando que se D. Pedro "quer ser rei só do Brasil, declare-o de uma vez, para conhecermos que é o primeiro dos reis brasilienses, em cujo nome deve começar a história da nação brasílica"55. Para muitos dos estrangeiros aqui presentes, como Mareschal - seguidor fiel dos princípios da monarquia absoluta, como o próprio Metternich a quem servia -, a convocação da Assembléia fora obra do "partido anárquico", de João Soares Lisboa, José Clemente Pereira, Januário da cunha Barbosa e Joaquim Gonçalves Ledo.

Para os "democratas", porém, o decreto de convocação era a vitória mais significativa das tentativas de trazer o Povo - a representação política da boa sociedade, isto é, daqueles que eram livres e proprietários de escravos, representavam-se como brancos, e não se confundiam com a plebe - para o primeiro plano da cena política. Para eles, o Povo era identificado à vontade da maioria, pressupondo uma igualdade que se projetava na proposta de eleição direta e repudiava a representação por uma porção qualificada.

Quando, pouco mais de um mês depois, por ocasião da reunião do Conselho de Procuradores, Joaquim Gonçalves Ledo se dirigiu ao Príncipe-Regente para reafirmar sua posição e solicitar licença para dirigir-se aos seus constituintes, por meio de seu jornal, ele defendeu, novamente, a eleição direta para a escolha dos representantes do Povo. Argumentava, então: "Senhor. Quando o Povo tem uma vez pronunciado seu juízo, é uma necessidade do Governo conformar-se com ele. Ousarei dizer a V. A. R. que é uma verdade quase dogmática no Regime Constitucional. "Ouem governa com o Povo, governa com a força". O Povo tem já no objeto de que se trata expendido os seus sentimentos. - Nomeação Direta -. É do meu dever aconselhar a V. A. R. que se não oponha à corrente impetuosa da opinião pública: não se irritem ânimos que começam a acalmar-se. Soam ainda os longos e veementes discursos acabados de recitar nas Cortes de Portugal a favor das eleições diretas. 0 congresso de Lisboa só aberrou da estrada constitucional quando tratou do Monarca, e do Brasil; fujamo-Ihes dos erros mas não desprezemos o que ele fez de bom e nos é adaptável. 0 Povo de Portugal não é mais instruído que o do Brasil[...] Eu nunca chamarei deliberação bem entendida aquela em que se confundirem os direitos dos homens com as suas faculdades físicas ou morais. A vontade do maior número deve ser a lei de todos. 0 maior número pede as eleições diretas, a Lei as deve sancionar. Só por elas é que se pode dizer que o Povo nomeou os seus representantes; de outro modo são os representantes da porção que se intitula seleta. Provera a Deus que o Brasil não se ressentisse desse modo de eleições!" 56

0 decreto de convocação não deixava de enfatizar alguns dos princípios caros aos "democratas"; todavia, ele não se esquivaria de hierarquizar as razões de uma convocação, assim como as forças que por ela haviam se empenhado, do que resultava um deslocamento da significação que os "democratas" atribuíam a Povo, por meio da reafirmação de hierarquias. Ele não deixaria de se referir também a uma herança que possibilitava demarcar uma autonomia: "Havendo-me representado os Procuradores Gerais de algumas Províncias do Brasil já reunidos nesta Corte, e diferentes Câmaras, e Povo de outras, o quanto era necessário, e urgente para a mantença da Integridade da Monarquia Portuguesa, e justo decoro do Brasil, a Convocação de uma Assembléia Luso-Brasiliense, que investida daquela porção de Soberania, que essencialmente reside no Povo deste grande, e riquíssimo Continente, Constitua as bases sobre que se devem erigir a sua Independência, que a Natureza marcara, e de que já estava de posse, e a sua União com todas as outras partes da Grande Família Portuguesa..." 57

A impossibilidade da manutenção da autonomia e do exercício de uma preponderância no Reino Unido - uma "escravização"- conduziu à eman- 
58

Idem, p.99.

59

Cf. Francisco Adolfo de Varnhagen. "História da independência do Brasil". In: História Geral do Brasil. 6a ed. São Paulo: Melhoramentos, 1978.

60

Jean Baptiste Debret. Viagem pitoresca e histórica ao Brasil. Tomo II. São Paulo: Martins, 1965, p. 274. cipação política. Naquela oportunidade, os diferentes nomes - Brasil [o genérico nome de...]; Reino do Brasil; Império do Brasil - já não podiam coexistir; opunham-se, porque não deixavam de exprimir projetos políticos concorrentes. A opção por Império do Brasil resgatava uma herança; expressava o primeiro momento de triunfo de um projeto; revelava como os herdeiros eram também construtores; reafirmava o papel da cidade do Rio de Janeiro como cabeça; e evidenciava, sobretudo, como uma denominação distinguia-se, desde então, por enfeixar uma pluralidade de significações.

No momento em que um continente parecia começar a encontrar o seu novo conteúdo, Vasconcelos Drumond, um correligionário de José Bonifácio, comentaria que não conhecia outro exemplo de uma revolução que tivesse preservado tantos privilégios. Uma revolução que não tardava em inscrever-se na alma e no corpo de cada um dos brasileiros, quer por meio dos versos de Evaristo da Veiga - "ou ficar a Pátria livre ou morrer pelo Brasil"-, quer por meio da ação política de José Bonifácio - como o revela o decreto que determinava, já no dia 18 de setembro de 1822, que "todo o português europeu, ou o brasileiro, que abraçar o atual sistema do Brasil, e estiver pronto a defendê-lo usará por distinção a flor verde dentro do ângulo de ouro no braço esquerdo, com a legenda Independência ou Morte", impondo aos que não o fizessem a saída do território do Império em determinado período de tempo, transformando assim os portugueses no segundo dos estrangeiros do novo corpo político 58 .

Entre a Aclamação de D. Pedro como Imperador constitucional e defensor perpétuo do Brasil, realizada no Campo de Santana no dia 12 de outubro, e a cerimônia de Coroação, na Capela Imperial, no dia $1^{\circ}$ de dezembro de 1822, o poder dos Andradas - em particular o de José Bonifácio - se expandiu de modo imperial, provocando o afastamento dos "democratas" da cena política, não raro por meios violentos.

A Coroação foi majestosa. 0 plano do cerimonial não deixava de revelar o projeto que ia se impondo, em um momento novo. Adotaram-se partes do que tivera lugar na sagração de Napoleão I, combinadas com o que se praticava na Áustria, inclusive a cerimônia da Hungria de fender o ar com a espada59.

A cerimônia se desdobraria na representação extraordinária dada no teatro da Corte, uma vez que, - como anotaria J. B. Debret - "não podia o teatro permanecer estranho a esse movimento". Afinal, naqueles dias, "via-se a energia nacional dividir-se entre os preparativos suntuosos da coroação e as atividades militares destinadas a rechaçar do território imperial os exércitos portugueses ainda refugiados em alguns pontos do litoral". Ele fora encarregado de pintar o novo pano de boca, "cujo bosquejo representava a fidelidade geral da população brasileira ao governo imperial", e seria aprovado por José Bonifácio60.

A representação na representação - saudada "por aplausos prolongados ... [que] completaram esse dia de triunfo"- somava-se a um conjunto de decisões, medidas e propostas que, desde então, anunciavam uma expansão de cunho imperial e perseguiam uma unidade. Uma expansão e uma unidade possiveis de serem concretizadas porque referidas à ação de uma autoridade única e centralizada, capaz de restaurar o princípio aglutinador - o mesmo que teria impedido a desertificação e a decadência do velho Reino português, conforme enunciara Andrada, como um filósofo, em sua Memória de 1815. Mas uma representação que também punha em destaque os elementos que tornavam possivel, àquela autoridade única e centralizada, uma ação regeneradora: paulistas e mineiros, em plano destacado; índios armados e soldados brasileiros; uma família negra; caboclos ...

Decisões como a criação de um escudo de Armas, de modo a também "honrar as 19 Províncias compreendidas entre os grandes rios que são os seus limites naturais, e que formam a sua integridade"; da Ordem Imperial do 
61

Cf. Octaciano Nogueira. Op. cit., p.101, p.108 e p. 128 , respectivamente.

62

Idem, p.99.

63

Idem, p.239.

64

José Bonifácio de Andrada e Silva.

"Apontamentos para a civilização dos

indios bravos do Brasil" e "Representação à

Assembléia Geral Constituinte e Legislativa

do Império do Brasil sobre a escravatura". In: Miriam Dohlnikoff (org.) José Bonifácio de

Andrada e Silva. Projetos para o Brasil. São Paulo: Cia. das Letras, 1998.

65

José Bonifácio de Andrada e Silva. Op. cit., p. 47.

66

Citado por José Honório Rodrigues.0p. cit., p. 318.

67

Cf. Benedict Anderson. Nação e consciência nacional. São Paulo: Ática, 1989.
Cruzeiro; e de uma Guarda de Honra, composta de três esquadrões: do Rio de Janeiro, São Paulo (reunião em Taubaté) e Minas Gerais (reunião em S. João del Rei). E ainda a elevação à categoria de cidade de todas as vilas que fossem capitais de províncias, ao mesmo tempo em que concedia títulos honoríficos às povoações de Vila Rica, São Paulo, Itu, Sabará e Barbacena, por sua "resolução de sustentar, ainda à custa dos maiores sacrifícios, os direitos inauferíveis dos povos do Brasil contra os seus declarados inimigos"61.

Medidas que objetivavam, prontamente, fazer coincidir o novo corpo político com os limites do vasto território apropriado como uma herança, o que de imediato se desdobrava nas "atividades militares destinadas a rechaçar do território imperial os exércitos portugueses ainda refugiados em alguns pontos do litoral", nas palavras de Debret. Discorrendo sobre os acontecimentos no Pará, José Bonifácio dizia, em abril de 1823, que "...não podia o Pará separar-se impunemente do todo a que pertence, nem S.M. consenti-Io, depois de ter jurado a defesa, e conservação dos direitos de seus fiéis súditos, e da integridade do território do Império"62.

0 triunfo das forças imperiais não representava apenas a expulsão das tropas fiéis às Cortes portuguesas das províncias conflagradas; a Guerra de Independência significava também a primeira tentativa de expansão do Império do Brasil, com o objetivo de ligar aquelas províncias a um projeto político gestado no Rio de Janeiro, de modo que compartilhassem de uma identidade politica diversa - brasileiros.

Medidas e decisões que sublinhavam o papel e o valor do conjunto de forças que tornaram possivel o rompimento com as Cortes portuguesas e, agora, sustentavam uma expansão. $E_{1}$ dentre elas, ao lado daqueles interesses presentes no Rio de Janeiro, destacavam-se paulistas e mineiros, motivando a decisão do governo imperial de autorizar "uma subscrição para um monumento à Independência do Império no sítio denominado Ipiranga"63.

Medidas e decisões que se somavam às propostas, de José Bonifácio, de incorporação dos indios bravos e dos negros escravizados a uma nova nação - a nação brasileira -, expostas em memórias ${ }^{64}$ apresentadas à Assembléia Constituinte. Eram também expressão da estrita filiação do velho Andrada, cristão e filantropo, à tradição do reformismo português. A civilização dos índios bravos e a emancipação dos negros escravos, ainda que gradual, constituiam-se em condição para evitar uma "escravização": "Se o antigo despotismo foi insensivel a tudo, assim Ihe convinha ser por utilidade própria: queria que fossemos um povo mesclado e heterogêneo, sem nacionalidade, e sem irmandade, para melhor nos escravizar. Graças aos céus, e à nossa posição geográfica, já somos um povo livre e independente. Mas como poderá haver uma Constituição liberal e duradoura em um país continuamente habitado por uma multidão imensa de escravos brutais e inimigos?"65.

Tendo como pano de fundo uma tradição, a figura de José Bonifácio não deixava de contrastar, sublinhando semelhanças e diferenças, com a de Gonçalves Ledo, que em certa ocasião, nas páginas do Revérbero Constitucional Fluminense, dissera ser uma nação "a reunião dos povos, que obedecem à mesma lei e ao mesmo sistema de governo. As classes privilegiadas, que gozam de foros e exceções de lei, não constituem nação, são pequenas frações da grande massa, em que só reside a força, o poder e a soberania"66.

No essencial, a constatação de Saint-Hilaire permanecia viva, revelando a outra face de uma herança. A independência política criara a liberdade frente à dominação metropolitana; mas não fora capaz de gerar uma unidade, do ponto de vista de uma nação moderna, constituida por indivíduos livres e iguais perante a lei e partícipes de uma mesma comunidade imaginada 67 . Elementos de fundo racial, social e cultural combinavam-se, de modo original, aos atributos de liberdade e propriedade no estabelecimento de fronteiras, embora não inteiramente impermeáveis, entre a boa sociedade, o povo mais ou menos miúdo e a massa de escravos. A liberdade do corpo político combi- 
68

Diário da Assembléia Geral Constituinte e Legislativa do Império do Brasil. V. III.(edição fac-similar) Brasília: Senado Federal, 1972, p. 10. Sessão de 15 de setembro de 1823.

69

Idem, p. 36. Sessão de 17 de setembro de 1823.

70

Diário da Assembléia Geral Constituinte e Legislativa do Império do Brasil. V. II. (edição fac-similar) Brasília: Senado Federal, 1972, p. 98. Sessão de 15 de junho de 1823. nava-se às hierarquizações que presidiam não só as relações entre aqueles três segmentos da sociedade, mas também no interior de cada um deles, atribuindo lugares e determinando papéis e funções às pessoas e coisas (entenda-se, os escravos) que os constituiam. A liberdade política não apenas não se desdobrara em unidade; ela repelia a igualdade, deixando-se guiar por um sentimento aristocrático que se apresentava como uma espécie de gramática para todos aqueles que reproduziam, a cada instante, as hierarquias e as práticas hierarquizantes que definiam a sociedade.

Contudo, a questão da unidade insistia em se colocar quase que exclusivamente sob o aspecto da manutenção de um território, como condição para conter em sua integridade o novo corpo político em construção. Reunida a Assembléia Constituinte, aquela face da herança nortearia grande parte das discussões do projeto constitucional.

"O terreno e a população; o Território e os Cidadãos seus habitantes, são as duas idéias simples, que formam a complexa de Reino, Império ou Nação: esta jamais se pode conceber sem aquelas", afirmava Montezuma, na sessão de 17 de setembro. Assim se apresentava a questão do território, logo por ocasião da discussão do artigo inicial que tratava dos limites do vasto Império do Brasil. Às propostas de uma definição explícita dos seus limites, entendida como fundamental para a preservação de uma herança, contrapunham-se não só os que alegavam a impossibilidade de fazê-lo, em decorrência das insuficientes informações disponíveis, assim como os que, como Montezuma, sustentavam que "somente se deve designar as partes de que se compõe, nomeando as Províncias; feito isto com a declaração que se acha no Art. $3^{\circ}$ de que a Nação não renuncia ao direito que possa ter a quaisquer outras possessões"68. 0 que não só parecia repetir a formulação de Hipólito José da Costa, no número inicial do Correio Braziliense, como também deixava transparecer a lógica imperial que informava seu argumento, ainda que em um quadro radicalmente diverso.

Ela se desdobraria, de modo quase inevitável, nas discussões a respeito das relações entre as províncias e a cabeça do novo Império. A solução federativa proposta para a Cisplatina seria recuperada por aqueles que defendiam uma organização federativa também para o novo império, os quais não raro argumentavam que ao governo do Império, no momento em que se desenrolavam os acontecimentos relacionados à Guerra de Independência, faltavam "forças" e "direito" para obrigar as províncias a uma união, caso as mesmas optassem pela separação, e que agir ao contrário, seria demonstrar um despotismo semelhante ao das Cortes de Portugal em relação ao Brasil69.

Diversa não poderia deixar de ser a compreensão de José Bonifácio. Em pronunciamento no dia 15 de junho, às vésperas da queda do ministério e de sua passagem para a oposição, ele se esforçava por identificar as diferentes tendências políticas. Afirmava, então: "brasileiro é para mim todo homem que segue a nossa causa", estabelecendo, assim, uma distinção entre "não separatistas" e "separatistas". Estes - isto é, os brasileiros - dividiam-se em corcundas, republicanos, monarquistas constitucionais e federalistas. Se os corcundas "querem a separação, mas não a liberdade", os republicanos não entendem "que o Brasil por voto unânime não quisesse ser república"; e os monárquico-constitucionais que "fitam suas vistas na felicidade do Estado, não querem democracias nem despotismo", enquanto os defensores da federação - "bispos sem papa" - queriam "um governo monstruoso; um centro de poder nominal, e cada província uma pequena república, para serem nelas chefes absolutos, corcundas despóticos"70. Na concepção do Andrada, a preservação de uma herança em sua integridade implicava a centralização política, e a esta associava-se não apenas a monarquia constitucional - "a liberdade bem entendida, e com estabilidade" -, mas sobretudo a idéia imperial.

A herança impunha-se, assim, a quase todos os componentes da boa sociedade: na cabeça do novo corpo político e nas províncias que o compu- 
71

Frei Caneca. "Crítica da Constituição outorgada". In: Ensaios políticos. Rio de Janeiro: PUC-Rio/CFC/Ed. Documentário, 1976, p. 70

72 Octavio Tarquinio de Souza. Op. cit., p. 45.

\section{3}

Justiniano José da Rocha. "Ação, Reação, Transação. Duas palavras acerca da atualidade política do Brasil". In: Raimundo Magalhães Junior (org.). Três panfletários do segundo reinado. São Paulo: Cia. Editora Nacional, 1956, p. 171.

\section{4}

Cf., entre outros, Raymundo Faoro. A formação do patronato político brasileiro. Porto Alegre: Ed. Globo, 1958. nham; nos salões da Corte, na Assembléia Constituinte e na imprensa de opinião. Uma herança que gerava sentimentos diversos e apropriações diferenciadas.

Ela se constituiria em argumento poderoso de oposição ao governo de Dom Pedro I. Ao comentar, em 1824, o projeto de Constituição, que 0 imperador submetia à apreciação e juramento das câmaras municipais, Frei Caneca sustentava ser aquela herança condição para dissociar em definitivo o Brasil de Portugal. Reforçando os argumentos que acabariam por conduzir à Confederação do Equador, dizia que, além do projeto não determinar "positiva e exclusivamente o território do império", deixando assim a possibilidade de uma união com Portugal, o imperador havia jurado "a integridade e indivisibilidade do império", [mas] "não jura a sua independência"71.

Em sua contundência na defesa de um corpo político em construção, os argumentos do frei não deixavam de operar também com aquela herança: um nome, um território, um projeto de nação.

\section{Uma Expansão Para Dentro}

Nada além de uma simples coincidência, a Confederação do Equador situando-se entre o início do eclipse político do velho Andrada e a parte final do período de "recolhimento e de íntima preparação" de Evaristo da Veiga, anunciando sua projeção na vida política ${ }^{72}$. Mas uma coincidência que permite sublinhar também a mudança no modo de se apropriar de uma herança, que deixava de atuar como âncora, e assim assegurando uma continuidade, para se apresentar, sobretudo, como uma catapulta, projetando algo novo, que se expressaria em uma mudança radical do significado atribuído ao Império do Brasil - isto é, à própria noção de império.

0 antigo nome, que permanecia para designar o novo corpo político, tinha o poder de emocionar a muitos, suscitando orgulho e esperança. Não deixava de insinuar, porém, uma certa continuidade em relação à ordem anterior, até mesmo porque no centro dos acontecimentos daqueles anos, tidos como decisivos, encontrava-se muitas vezes o próprio herdeiro do trono português. E tal expressava-se em temor, intranqüilidade e insegurança a respeito do futuro do novo corpo político; assim como em sentimentos de fundo nativista que motivariam, quase três décadas depois, o comentário arguto de um panfletário de que "o caráter das primeiras lutas do Brasil pode antes ser considerado social do que político; o espírito democrático não aparecia em primeira linha, em primeira linha estavam os ciúmes nacionais".73

Os acontecimentos do Primeiro Reinado revelam tais sentimentos, no encaminhamento dado às questões relativas a sua organização interna e à condução dos negócios externos. Cuido, resumidamente, de cada uma dessas questões tendo em vista a compreensão daquela mudança radical de significado.

A questão da organização interna, em primeiro lugar. A presença do constitucionalismo - cuja força era potencializada à medida que a atuação política do primeiro imperador parecia revestir-se, aos olhos de seus opositores, de um sentido inequívoco - possibilitava que fossem solapadas as bases tradicionais do poder do soberano, ligadas às práticas do Antigo Regime, o que repercutia no próprio fundamento do Império. Revelam-no, entre outras, as seguintes medidas: a Resolução de 17 de julho de 1822, que suspendia toda e qualquer concessão de sesmarias, afetando a lógica do poder territorialista; a lei de $1^{\circ}$ de outubro de 1828 que "dá nova forma de Câmaras Municipais, marca suas atribuições, e o processo para sua eleição e dos Juízes de Paz", e ao transformar as câmaras em corporações meramente administrativas, alterava significativamente a relação entre soberano e povo; e a organização do Poder Judiciário, na qual assumiam relevo a criação do Supremo Tribunal de Justiça e a promulgação do Código Criminal em 1830, quebrando o monopólio da justiça pelo soberano ${ }^{74}$. 
75

Cf. José Honório Rodrigues. Brasil e África: outro horizonte. $2^{\text {a }}$ edição. Rio de Janeiro: Civilização Brasileira, 1964, pp. 131-181.

76

Cf., a respeito, Ilmar Rohloff de Mattos. "A moeda colonial em restauração". In: 0 tempo saquarema. p. 84

77

Cf., entre outros, Luis Cláudio Villafañe Gomes Santos. O Império e as repúblicas do Pacífico. As relações do Brasil com Chile, Bolivia, Peru, Equador e Colômbia (18221889). Curitiba: Ed. da UFPR, 2002.

78

A respeito das vicissitudes da "questão platina", cf. João Paulo G. Pimenta. Estado e nação no fim dos impérios ibéricos no Prata (1808-1828). São Paulo: Hucitec/ Fapesp, 2002.

79

Cf. a respeito IImar Rohloff de Mattos. 0 tempo saquarema.
Os negócios externos, agora. Neles, o reconhecimento da independência e a questão da Província Cisplatina assumem uma importância singular, sendo acompanhados pelo incidente de Chiquitos. No primeiro caso, o papel inconteste coube ao Império britânico, e especificamente ao Foreign Office sob a liderança de George Canning. A diplomacia britânica expulsaria o novo império das terras africanas, por meio do tratado firmado entre Dom Pedro I e seu pai, Dom João VI, que reconhecia a independência do Brasil, e do qual ela aparecia como fiadora. Punha-se um freio, assim, à crescente presença do Reino do Brasil no continente negro desde 1816, e frustrava-se o plano de tornar Angola independente, incorporando-a ao Império do Brasil. ${ }^{75}$ Os interesses expansionistas do capitalismo, que atingiriam seu ponto máximo sob o imperialismo, conflitavam abertamente com os interesses expostos por Bernardo Pereira de Vasconcelos em discurso no Senado em abril de 1843: "A África civiliza a América"76

0 incidente de Chiquitos, ocorrido no primeiro semestre de 1825, reforçaria a percepção, presente entre as novas repúblicas da América hispânica, de que o imperador do Brasil estava envolvido em uma conspiração arquitetada pela Santa Aliança com propósitos restauradores. 0 desfecho do episódio não alteraria esta percepção, até mesmo porque a situação da Cisplatina permanecia indefinida, o que faria com que a politica imperial relativa àquelas repúblicas se mostrasse cautelosa, desde então, evitando tanto apresentar-se com intenções expansionistas quanto um completo isolamento na América, sobretudo porque as expectativas a respeito da implantação de outros regimes monárquicos diminuíam progressivamente 77

No que diz respeito à questão da Cisplatina, o papel da diplomacia britânica não seria menos decisivo, intermediando a paz entre o Império do Brasil e a República das Províncias Unidas do Rio da Prata, por meio da criação da República Oriental do Uruguai. A derrota das forças militares de Dom Pedro I em Ituzaingó revelava a incapacidade de um imperador expandir espacialmente os seus domínios, atestando uma impossibilidade. 78

Mas não apenas ali. 0 mesmo ocorria no continente africano, e em ambos os casos o papel do Império britânico fora decisivo. $E_{1}$ desde então, o novo Império do Brasil adquiria uma marca distintiva: a impossibilidade de um domínio ilimitado em termos espaciais.

"Queremos a Constituição!", enfatizara Evaristo da Veiga. A combinação entre os acontecimentos referidos à organização interna e os relacionados aos negócios externos criava um campo de possibilidades radicalmente diverso, que interferia nos projetos que se apresentavam, ao mesmo tempo em que por eles era, ao menos em parte, definido. Condições diversas que se expressariam em uma relação diversa entre um continente - o vasto território - e seu conteúdo - o corpo político independente e a nação que ele pretendia representar. Ou seja: a associação entre Império do Brasil e Nação brasileira ligava a noção de império a uma concepção nacional, no mesmo movimento em que dissociava aquela noção de uma concepção dinástica. 0 texto constitucional de 1824 documentaria essa nova associação ao sublinhar em seu artigo $6^{\circ}$ a estreita relação entre cidadania, nacionalidade e território:

"Art. $6^{\circ}$. São cidadãos brasileiros I. Os que no Brasil tiverem nascido, quer sejam ingênuos ou libertos, ainda que o pai seja estrangeiro, uma vez que este não resida por serviço de sua nação".

A trajetória da construção desta nova associação foi longa e tortuosa, estendendo-se para além do momento da emancipação política. Ela pressupôs a própria construção do Estado imperial, por ser esta a condição necessária à existência da nação ${ }^{79}$. Nesta oportunidade, talvez valha a pena chamar a atenção para três outros pontos.

0 primeiro diz respeito ao fato de que esta nova associação tornava o Império do Brasil também parte de um todo, mas de um modo radicalmente diferente da situação anterior - ou seja, não mais como parte da Monarquia 
80

Cf. Mary C. Karasch. A vida dos escravos no Rio de Janeiro, 1808-1850. São Paulo: Cia. das Letras, 2000, pp. 35-66. portuguesa. Os homens que forjaram a emancipação política e, sobretudo, aqueles que empenharam suas vidas na construção do Estado imperial esforçaram-se tanto por inscrever o Império do Brasil no conjunto formado pelas Nações Civilizadas, quanto por não permitir que os cidadãos do novo império perdessem de vista a pluralidade das nações e Estados - referida, sem dúvida, a uma prévia unidade cultural -, como condição para se obter nela um lugar, por meio de um jogo que sublinhava as semelhanças, as diferenças e ainda as inversões que cumpriam um papel justificador, como na sentença de Bernardo Pereira de Vasconcelos - "a África civiliza a América".

0 segundo deles remete à consideração de que a proposta de associação entre Império do Brasil e Nação brasileira - ou, dizendo de outra maneira, a representação um Império = um Estado = uma Nação - ocorria em uma sociedade de base escravista e que herdara da colonização a convivência forçada entres três grupos étnicos. As diferenças e hierarquizações entre a boa sociedade - aqueles que eram livres, proprietários de escravos e representavam-se como brancos -, a plebe - aqueles que eram livres, não eram proprietários de escravos e eram representados nem como brancos nem como negros - e os escravos - aqueles que eram propriedades de outrem e não eram brancos - eram construídas a partir dos atributos primários de liberdade e propriedade (de escravos), e matizadas por critérios raciais e culturais, o que colocava em questão o conceito moderno de nação.

A rejeição da proposta de José Bonifácio, contida na memória sobre a escravatura, significava a opção dos dirigentes imperiais pela manutenção da escravidão. Significava, antes de tudo, a opção pela convivência da nação brasileira, que estava sendo forjada, com outras "nações" no interior do mesmo território unificado e contíguo. Não por acaso, no Rio de Janeiro imperial utilizava-se com relativa freqüência a expressão "nação" para identificar os escravos negros e ameríndios 80 , embora não se deixasse de discriminar entre as "nações de cor" - os escravos nascidos no Brasil - e as "nações africanas", até mesmo porque caso estes se tornassem libertos não se tornariam cidadãos brasileiros de acordo com o texto constitucional, ao passo que aqueles das "nações de cor" uma vez libertos não podiam ser eleitores de $2^{\circ}$ grau. Assim, às diferenças e hierarquias presentes na sociedade correspondiam as diferenças e hierarquizações entre a nação brasileira e as demais "nações", pondo em evidência a noção de ordem que também identificaria a experiência imperial brasileira.

A clareza do texto constitucional - "são cidadãos brasileiros os que no Brasil tiverem nascido, quer sejam ingênuos ou libertos" - auxilia na caracterização de um terceiro ponto. Por seu intermédio, o território retorna, mas de um modo radicalmente diverso: ele não só contribuia para definir quais indivíduos estavam habilitados a constituir a nação brasileira, fazendo coincidir a extensão do direito de cidadania com sua própria extensão, como servia para afirmar um dos elementos que singularizavam o Império do Brasil, uma vez que este se encontrava impossibilitado de expandir suas fronteiras espaciais. 0 papel e o valor atribuidos ao território seriam demonstrados sobejamente pelo saquarema José Antônio Pimenta Bueno, marquês de São Vicente, duas décadas depois da morte de Evaristo da Veiga, ao comentar a Constituição de 1824: "o território do Império não constitui somente a sua mais valiosa propriedade; a integridade, a indivisibilidade dele é de mais a mais não só um direito fundamental, mas um dogma político. É um atributo sagrado de seu poder e de sua independência; é uma das bases primordiais de sua grandeza exterior".

E ainda mais. Ultrapassados o período da "Ação" - no qual as experiências referidas ao "princípio democrático" não raro buscavam resgatar franquias, foros e privilégios de um regime antigo, ainda que sob uma roupagem nova - e o período da Reação - no qual a imposição da ordem imperial, muitas vezes por meios excessivamente violentos, faria com que 
81

José Antônio Pimenta Bueno, marquês de São Vicente. Direito público e análise da Constituição do Império. Brasilia: Senado Federal, 1978, p. 21. muitos a associassem a uma restauração de cunho absolutista -, o momento da "Transação" se distinguia por um padrão de relacionamento diverso entre o Governo da Casa e o Governo do Estado, a Liberdade e a Autoridade, as Províncias e o Governo Geral, o que ensejaria o comentário do marquês de São Vicente que "o império é um e único, [...] ele não é dividido em províncias senão no sentido e fim de distribuir convenientemente os órgãos da administração, de modo que em toda a extensão do país haja centros adequados e próximos para o serviço e bem ser dos respectivos habitantes". Nele, as províncias "não são estados distintos, ou federados, sim circunscrições territoriais, unidades locais, ou parciais de uma só e mesma unidade geral. São centros de vida, de ordem, e de ação administrativa, partes integrantes do império81 ".

A associação entre Império do Brasil e Nação brasileira atribuía um significado novo à noção de Império, sublinhando uma singularidade. Esta consistia tanto no lugar reivindicado para o Império pelos dirigentes imperiais no conjunto das Nações civilizadas, o qual se desdobrava numa determinada concepção de ordem, quanto na impossibilidade de um domínio ilimitado. 0 que acabava por reservar um valor especial ao território unificado e contíguo, elemento fundamental na definição de brasileiro que não mais deveria se restringir a uma dimensão política. Mas isto não era tudo.

A associação entre Império do Brasil e Nação brasileira era propiciada pela construção do Estado imperial. E esta construção, por sua vez, impunha a própria constituição da Nação. À dominação das demais "nações" somavase a direção pelo Governo do Estado daqueles brasileiros em constituição, o que implicava um padrão diverso de relacionamento entre aquele governo e o da Casa, "quebrando" as identidades geradas pela colonização, por meio da difusão dos valores, signos e símbolos imperiais, da elaboração de uma língua, uma literatura e uma história nacionais, entre outros elementos. Impossibilitado de expandir suas fronteiras, o Estado imperial era obrigado a empreender uma expansão diferente: uma expansão para dentro. E aí reside o traço mais significativo na construção de uma unidade.

Situados naquela "outra cidade", com sua fisionomia nova, os dirigentes imperiais orgulhosos da construção empreendida pareciam admirar as figuras de José Bonifácio e Evaristo da Veiga, três décadas após ter raiado a liberdade no horizonte do Brasil. 